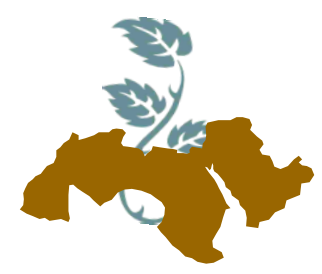

\title{
SOWING DATE AND IRRIGATION EFFECTS ON PRODUCTIVITY AND WATER USE EFFICIENCY IN SUNFLOWER
}

\author{
Shahin $^{1}$ M.G., EI-Bially ${ }^{1}$ M.E., Saudy ${ }^{1}$ H.S. and EI-Metwally ${ }^{2}$ I.M. \\ 1- Agronomy Dept., Fac. Agric., Ain Shams Univ., P.O. Box 68-Hadayek Shoubra 11241, \\ Cairo, Egypt \\ 2- Botany Dept., Nation. Res. Cent., P.O. Box 12622-Dokki, El-Behos St., Giza, Egypt
}

Keywords: Sunflower yield, Irrigation, Planting date, Abiotic stress, Water use efficiency

\section{ABSTRACT}

Abiotic stresses represent a major impediment to crop productivity, especially in arid regions. Thus, over two years of 2014 and 2015, a field experiment was undertaken at El Nubaria region, Egypt to assess the productivity and water use efficiency (WUE) of sunflower as affected by planting dates (April 21, May 21, and June 21) and irrigation levels $\left(\mathrm{ET}_{100 \%}, \mathrm{ET}_{85 \%}\right.$ and $\mathrm{ET}_{70 \%}$ ). Results clarified that leaf chlorophyll a content was higher by sowing in May than in either April or June sowings, while leaf carotenoides of plant sown in May or June surpassed those sown in April. The minimal value of proline was obtained with sowing in May. Sowing in May increased plant height by 52.2 and 22.3 as well as LAl by 19.3 and $73.1 \%$ than sowing in April and June, respectively. The reductions in seed yield, oil yield and WUE amounted to 10.5 and $12.8,13.7$ and 18.3 as well as 11.8 and $9.8 \%$ with April and June sowings, respectively, compared to May sowing. $\mathrm{ET}_{100 \%}$ showed superiority over than $\mathrm{ET}_{85 \%}$ and $\mathrm{ET}_{70 \%}$ in improving sunflower yields and its attributes, but WUE did not affect. Sunflower sown in May and irrigated with $\mathrm{ET}_{100 \%}$ gave the maximum values of seed yield and its attributes and WUE surpassing other interaction treatments. In June, WUE value increased under severe water deficit i.e. $\mathrm{ET}_{70 \%}$ comparing to moderately water-stressed $\left(\mathrm{ET}_{85 \%}\right)$ or well-watered conditions $\left(\mathrm{ET}_{100 \%}\right)$.

\section{INTRODUCTION}

Although the strategic importance of oilseed crops for Egyptian people could not negligible, Egypt is suffering from a huge gap of oil ranging between $87-90 \%$. There are many annual oil crops can be cultivated, however, the area devoted for this purpose is limited, not exceeding $1.58 \%$ of the total crop acreage (CAPMAS, 2014) ${ }^{\star}$. This is due to the intense competition between oil crops and other strategic, notably grain and forage, ones. For shrinking this issue, the expansion vertically and horizontally is crucial. However, in dry land cropping systems, water is the most important limiting factor for crop production (Ashrafi and Razmjoo, 2009). Regarding oil production, sunflower is one of the four most important oilseed crops (Demir et al 2006). It represents a source of high quality edible oil containing about $55-65 \%$ of linoleic acid, $20-30 \%$ oleic and different fatty acids (Joksimovic et al 2006). In addition, because of the seed has high oil and protein, being $36-52 \%$ and $28-32 \%$, respectively (Rosa et al 2009) as well as the extracted oil has low cholesterol and high unsaturated fatty acids (Flagella et al 2002; Qahar et al 2010) which suit proper nutrition, sunflower has been receiving trustworthy attention. Sunflowers, moreover, can response well under different climatic and soil conditions (Kaleem et al 2011).

Drought is one of the major constraints to crop production in the world (Farooq et al 2012). Increasing disquiet of water incompetence and more continual and harsh drought due to climate change has stimulated research toward water-aving irrigation programs aiming at producing more 'crop per 
drop' (Dodd, 2009; Morison et al 2008). In this respect, usage water below full crop-water requirements is regarded one of the significant pattern to overcome shortage water resources through diminishing irrigation water amounts (Fereres and Soriano 2007; Kang et al 2000). Such practice planed to improve water savings in agriculture (Bashir and Mohamed, 2014) but it should be performed taking crop species into account. Productivity of sunflower is mightily regulated by the availability of water and greatest yield losses manifest when water shortage occurs (Yawson et al 2011).

Different climatic conditions based on temperature predominant in varying seasons during the crop growth stages may lead to variations in yield components (KII and Altunbay, 2005). Solar radiation, air temperature and rainfall as crop growth factors are related with sowing dates (Aguirrezábal et al 2003; Izquierdo et al 2009).

Temperature is considered the main factor that affects plant growth, development and productivity (Aiken, 2005; Kaleem et al 2009). High temperature stress can also be avoided by crop management practices such as selecting proper sowing methods, choice of sowing date, cultivars, irrigation methods, etc (Hasanuzzaman et al 2013). Temperature variations in the field can be created by planting crops at different dates in the season, thus crop will grow at different temperature, sunshine, and relative humidity (Qadir et al 2007).

Unfavorable temperatures and low water supply, as abiotic stresses, promote overproduction of reactive oxygen species (ROS) in plant cell which are highly reactive and toxic and eventually results in oxidative stress (Gill and Tuteja, 2010). Elevated levels of ROS lead to the inactivation of proteins and inhibit the activity of multiple enzymes involved in metabolic pathways, and result in the oxidation of other macromolecules including lipids and DNA (Hossain et al 2014). Therefore, plant cells are equipped with splendid antioxidant defense mechanisms to detoxify the harmful effects of ROS.

For this, determining the optimum irrigation scheduling coupling with sowing date of sunflower under the newly reclaimed lands was the aim of this study.

\section{MATERIALS AND METHODS}

During 2014 and 2015 seasons, a field experiment was performed at the experimental farm of National Research Centre, El-Nubaria region, El-
Behaira Governorate, Egypt (latitude $30^{\circ} 30^{\prime} 1.4^{\prime \prime}$ $\mathrm{N}$, longitude $30^{\circ} 19^{\backslash} 10.9^{\prime \prime} \mathrm{E}$, and mean altitude 21 $\mathrm{m}$ above sea level). The experimental soil was sandy with $\mathrm{pH} 8.3$ and EC $0.38 \mathrm{dS} \mathrm{m}^{-1}$. The study area belongs to arid regions with no rainfall and hot dry in summer (April-September). The preceding cultivated crop was wheat in both seasons.

The study aimed to investigate the effect of irrigation water levels and sowing dates on productivity and water use efficiency (WUE) of sunflower (Helianthus annuus) under the environmental conditions of the study's area.

The study comprised nine treatments, which were the combinations of:

1. Three sowing dates: April 21, May 21, and June 21, represent early, mid, and delayed dates, respectively.

2. Three irrigation water levels: 100,85 and $70 \%$ of crop evapotranspiration $\left(E T_{c}\right)$, denoting as $\mathrm{ET}_{100 \%}, \mathrm{ET}_{85 \%}$ and $\mathrm{ET}_{70 \%}$, and representing well-watered, moderately water-stressed, and severely water-stressed conditions, respectively.

The experimental design was a strip-plot with four replicates. The treatments of the two experimental factors were allocated as follows: sowing dates in the vertical plots, while irrigation levels in the horizontal ones. The experimental unit area was $12.25 \mathrm{~m}^{2}$, involving five ridges each of $3.5 \mathrm{~m}$ long and $0.7 \mathrm{~m}$ wide.

From weather factors, irrigation water requirement for sunflower was calculated by determining daily reference evapotranspiration $\left(\mathrm{ET}_{0}\right)$ as illustrated in Table 1 using FAO Penman-Monteith equation (Allen et al 1998). From $\mathrm{ET}_{0}$, crop evapotranspiration $\left(E T_{C}\right)$ was computed using the following equation according to Doorenbos et al (1977):

Where:

$$
E T_{c}=E T_{o} \times K_{c} \quad \ldots \ldots \ldots(1)
$$

$\mathrm{ET}_{\mathrm{c}}=$ Crop evapotranspiration $\left(\mathrm{mm} \mathrm{day}^{-1}\right)$;

$E T_{\circ}=$ Reference evapotranspiration $\left(\mathrm{mm}\right.$ day $\left.^{-1}\right)$, and

$\mathrm{K}_{\mathrm{c}}=$ Crop coefficient (0.6-1.2).

Amount of irrigation requirement was calculated according to Keller and Bliesner (1990) as follows:

$$
I R=E T_{c} \times L R \times .4 .2 / E_{a}
$$

Where:

$\mathrm{IR}=$ Irrigation requirement $\left(\mathrm{m}^{3}\right.$ fed $\left.^{-1}\right)$;

$\mathrm{LR}=$ Leaching requirement (\%), (15\%) and

$E_{a}=$ Water application efficiency, $(90 \%$ for trickle irrigation). 
Table 1. Means of monthly climatic parameters and reference evapotranspiration (ETo) during sunflower growth and development at El Nubaria region (averages of 2014 and 2015 seasons).

\begin{tabular}{|c|c|c|c|c|c|c|}
\hline \multirow{2}{*}{ Month } & \multicolumn{2}{|c|}{ Air temperature $\left({ }^{\circ} \mathrm{c}\right)$} & \multirow{2}{*}{$\begin{array}{c}\text { Relative } \\
\text { humidity } \\
(\%)\end{array}$} & \multirow{2}{*}{$\begin{array}{l}\text { Wind speed } \\
\left(\mathrm{m} \mathrm{sec}^{-1}\right)\end{array}$} & \multirow{2}{*}{$\begin{array}{l}\text { Solar radiation } \\
\left(\mathrm{MJ} \mathrm{m}^{-2} \mathrm{day}^{-1}\right)\end{array}$} & \multirow{2}{*}{$\begin{array}{c}\mathrm{ET}_{0} \\
\left(\mathrm{~mm} \mathrm{day}^{-1}\right)\end{array}$} \\
\hline & Minimum & Maximum & & & & \\
\hline April & 15.22 & 27.82 & 47.58 & 0.74 & 23.41 & 4.52 \\
\hline May & 17.00 & 29.93 & 47.11 & 0.78 & 23.37 & 4.68 \\
\hline June & 19.65 & 31.92 & 48.92 & 0.89 & 24.89 & 4.97 \\
\hline July & 21.39 & 33.11 & 55.47 & 0.86 & 24.95 & 5.21 \\
\hline August & 23.30 & 35.01 & 53.56 & 0.72 & 22.52 & 4.98 \\
\hline September & 21.61 & 33.68 & 52.78 & 0.57 & 19.34 & 4.75 \\
\hline
\end{tabular}

"Data obtained from Central Laboratory of Meteorology, Ministry of Agriculture and Land Reclamation, Egypt

Table 2 shows the irrigation amounts applied for sunflower based on irrigation level for each planting date. Plants were irrigated using drippers of $2 \mathrm{~L} \mathrm{~h}^{-1}$ capacity. Irrigation water was obtained from an irrigation channel passing through the experimental area, with $\mathrm{pH} 7.4$, and EC $0.35 \mathrm{dS} \mathrm{m}^{-1}$. Sunflower seeds (cv. Sakha-53) were sown in hills (3-5 seeds per hill), with $20-\mathrm{cm}$ distance on the ridge. At 15 days after sowing (DAS), plants were thinned to secure one plant per hill. Plants were irrigated by using drippers of $2 \mathrm{~L} \mathrm{~h}^{-1}$ capacity. Irrigation water was obtained from an irrigation channel passing through the experimental area, with $\mathrm{pH}$ 7.4, and EC $0.35 \mathrm{dS} \mathrm{m}^{-1}$.All other recommended cultural practices were applied throughout the two seasons.

Table 2. Calculated irrigation water amounts $\left(\mathrm{m}^{3}\right.$ fed $\left.^{-1}\right)$ used based on irrigation level and planting date of sunflower

\begin{tabular}{|l|c|c|c|c|}
\hline \multirow{2}{*}{$\begin{array}{l}\text { Sowing } \\
\text { date }\end{array}$} & \multicolumn{3}{|c|}{ Irrigation level } & Mean \\
\cline { 2 - 4 } & $\mathbf{E T}_{100 \%}$ & $\mathbf{E T}_{\mathbf{8 5} \%}$ & $\mathbf{E T}_{\mathbf{7 0} \%}$ & \\
\hline April & 2229.3 & 1894.9 & 1560.5 & 1894.9 \\
May & 2153.8 & 1830.8 & 1507.7 & 1830.8 \\
June & 2132.3 & 1812.5 & 1492.6 & 1812.5 \\
Mean & 2171.8 & 1846.0 & 1520.3 & \\
\hline
\end{tabular}

\section{Assessments}

\section{a. Physiological and growth traits}

At 60 DAS, four guarded plants were chosen randomly from each plot to estimate plant height and leaf area index (LAI). Then, the $4^{\text {th }}$ leaf from the top of each plant was used for carrying out the quantitative analysis of chlorophyll $a$ and carotenoides (Arnon, 1949) as well as free proline (Bates et al 1973).

\section{b. Yield and its attributes}

At harvest dates in 2014 and 2015 seasons (in July 23 and 27, August 6 and 12 and September 4 and for early, mid and delayed sowing date, respectively), whole plants of one middle ridge from each experimental plot were harvested to estimate head diameter, head weight plan $^{-1}$, seed index and seed yield $\mathrm{fed}^{-1}$. Seed oil percentage was measured by extraction using Soxhlet Apparatus with hexane as an organic solvent, according to A.O.A.C. (1995), and then oil yield $\mathrm{fed}^{-1}$ was calculated.

\section{c. Water use efficiency (WUE)}

To evaluate treatments with respect to maximum yield produced per unit of water applied in the field, WUE was computed. Seed moisture content was about $15.0 \%$ and the WUE was expressed as sunflower seed yield $(\mathrm{kg})$ per applied water $\left(\mathrm{m}^{3}\right)$, according to Pene and Edi (1996). 


\section{Statistical analysis}

Data were subjected to analysis of variance (ANOVA) according to Gomez and Gomez (1984), using Costat software program Version 6.303 (2004). The combined analysis of variance for the data of the two seasons was performed after testing the error homogeneity. The differences among means were compared using LSD test at 0.05 probability level.

\section{RESULTS AND DISCUSSION}

\section{Physiological and growth traits}

Analysis of variance proved remarked effects of sowing dates on physiological and growth traits of sunflower (Table 3). Leaves contained more chlorophyll $a$ and carotenoides for plants sown in May and June, respectively. In other words, leaf chlorophyll a content was higher by sowing in May than in either April or June sowings, while leaf carotenoides of plant sown in May or June surpassed those sown in April. Unlike chlorophyll a and carotenoides, the minimal value of proline was obtained with sowing in May (mid sowing). Marked leaf proline increase, however, was gained with early sowing (in April), and another increase was occurred with delayed sowing (in June). The increments in proline due to early or delayed sunflower sowing reached 5.5 and $12.1 \%$, respectively compared to sowing in May. Proline enrichment in the stressed plants is a general response to various abiotic stresses, hence it has been developed as effective indices for stress tolerance identification (AbdelNasser and Abdel-Aal, 2002). Moreover, proline accumulation in stressed plants has been well established to play a key role as osmoregulation defense mechanism, leading to prevent the cell osmotic pressure and survive in the extreme conditions (Sankar et al 2007). High proline accumulations in plant cells may reflect the reduction in lipid peroxidation products, acting as free radical scavenger and its binding with redox-active metal ions can prevent the biological tissues, damaging by $\mathrm{OH}^{\circ}$ free radicals (Hsu et al 2003). Increases in proline occur at moderate to severe stress levels (Khanna-Chopra, 2004).

Concerning the growth traits, reductions in plant height and LAl resulted due to sowing early (in April) or delayed one (in June) were observed (Table 3). Sowing in May increased plant height by 52.2 and 22.3 as well as LAI by 19.3 and $73.1 \%$ than sowing in April and June, respectively. Sever- al investigators have shown that delaying sunflower sowing date significantly decreased plant height (El-karamity et al 1998 and Sultan et al 1988) and LAl (Abd-El wahab et al 1992 and Ali et al 2004).

Our findings clarify that sowing sunflower in non-May, whether earliness or delay means exposure of plants to heat stresses, where reductions in chlorophyll $a$ and carotenoides as important photosynthesis pigments and increment in proline as an indicator of heat stress as well as decreases in growth traits were obtained due to early and delayed plantings compared mid sowing (Table 3). Temperature considered the primary factor governing crop growth rate (Baydar and Erbas, 2005).

Decreases in chlorophyll $a$, carotenoides, plant height and LAl as well as increase in proline due to lowering irrigation water below well-watered conditions were anticipated as illustrated in Table $\mathbf{3}$.

Irrigating sunflower plants using $\mathrm{ET}_{85 \%}$ and $\mathrm{ET}_{70 \%}$ treatments, representing moderately waterstressed and severely water-stressed conditions, respectively, markedly reduced chlorophyll $a$ by 24.2 and $33.6 \%$, carotenoides by 22.7 and $35.3 \%$, plant height by 8.6 and $18.8 \%$ and LAI by 36.0 and $51.7 \%$, while increased proline content by 87.2 and $221.6 \%$ respectively, compared to $\mathrm{ET}_{100 \%}$, i.e. wellwatered condition. It is well documented that various abiotic stresses, including drought, lead to the overproduction of ROS in plants which are highly reactive and toxic and ultimately results in oxidative stress (Gill and Tuteja, 2010). Being ROS are responsible for the damage to membrane and other essential macromolecules (such as photosynthetic pigments, proteins, DNA and lipids), chlorophyll $a$ and carotenoides reduction associated low water supply (Table 3). Under water deficit stress, chloroplast ultrastructures are the first targets to be damaged in the cellular levels since it is the major site of ROS production (Munné-Bosch and Peñuelas, 2003). The decrease in chlorophyll content under drought stress has been considered a typical symptom of oxidative stress and may be the result of pigment photo-oxidation and chlorophyll degradation. Photosynthetic pigments are important to plants mainly for harvesting light and production of reducing powers (Anjum et al 2011). Studies by majority of chlorophyll loss in plants in response to water deficit occurs in the mesophyll cells with a lesser amount being lost from the bundle sheath cells (Anjum et al 2011). Many investigators studies the effect of drought stress on growth attributes of sunflower plants. Increasing drought stress caused significantly decreased 

in sunflower

Table 3. Irrigation and planting date influences on sunflower physiological and growth traits

\begin{tabular}{|c|c|c|c|c|c|c|}
\hline \multirow{2}{*}{\multicolumn{2}{|c|}{ Treatment }} & \multicolumn{3}{|c|}{ Physiological trait } & \multicolumn{2}{|c|}{ Growth trait } \\
\hline & & $\begin{array}{c}\text { Chlorophyll a } \\
\left(\mathrm{mg} \mathrm{g}^{-1}\right)\end{array}$ & $\begin{array}{c}\text { Carotenoides } \\
\left(\mathrm{mg} \mathrm{g}^{-1}\right)\end{array}$ & $\begin{array}{l}\text { Proline } \\
\left(\mu g g^{-1}\right)\end{array}$ & $\begin{array}{c}\text { Plant height } \\
(\mathrm{cm})\end{array}$ & LAI \\
\hline \multicolumn{7}{|c|}{ Sowing date (S) } \\
\hline \multicolumn{2}{|l|}{ April } & 1.69 & 0.526 & 338.2 & 122.0 & 2.54 \\
\hline \multicolumn{2}{|l|}{$\begin{array}{l}\text { May } \\
\text { June }\end{array}$} & 1.73 & 0.589 & 320.7 & 185.7 & $\begin{array}{l}3.03 \\
1.75\end{array}$ \\
\hline \multicolumn{2}{|l|}{$\mathrm{LSD}_{0.05}$} & 0.03 & 0.017 & 15.8 & 3.6 & 0.18 \\
\hline \multicolumn{7}{|c|}{ Irrigation level (I) } \\
\hline \multirow{3}{*}{\multicolumn{2}{|c|}{$\begin{array}{l}\mathrm{ET}_{100 \%} \\
\mathrm{ET}_{85 \%} \\
\mathrm{ET}_{70 \%}\end{array}$}} & 2.11 & 0.708 & 167.3 & 165.8 & 3.44 \\
\hline & & 1.60 & 0.547 & 313.2 & 151.5 & 2.20 \\
\hline & & 1.40 & 0.458 & 538.0 & 134.7 & 1.66 \\
\hline \multicolumn{2}{|l|}{$\mathrm{LSD}_{0.05}$} & 0.01 & 0.010 & 14.7 & 3.6 & 0.12 \\
\hline \multicolumn{7}{|l|}{$S \times I$} \\
\hline \multirow[t]{3}{*}{ April } & $\mathrm{ET}_{100 \%}$ & 2.08 & 0.647 & 156.1 & 139.9 & 3.69 \\
\hline & $\mathrm{ET}_{85 \%}$ & 1.60 & 0.497 & 326.5 & 121.0 & 2.34 \\
\hline & $\mathrm{ET}_{70 \%}$ & 1.41 & 0.435 & 531.9 & 105.2 & 1.60 \\
\hline \multirow[t]{3}{*}{ May } & $\mathrm{ET}_{100 \%}$ & 2.17 & 0.745 & 151.4 & 200.6 & 4.25 \\
\hline & $\mathrm{ET}_{85 \%}$ & 1.64 & 0.552 & 295.1 & 189.5 & 2.77 \\
\hline & $\mathrm{ET}_{70 \%}$ & 1.38 & 0.470 & 515.7 & 167.1 & 2.06 \\
\hline \multirow[t]{3}{*}{ June } & $\mathrm{ET}_{100 \%}$ & 2.07 & 0.732 & 194.3 & 156.9 & 2.38 \\
\hline & $\mathrm{ET}_{85 \%}$ & 1.58 & 0.592 & 318.1 & 144.1 & 1.48 \\
\hline & $\mathrm{ET}_{70 \%}$ & 1.40 & 0.470 & 566.5 & 131.9 & 1.30 \\
\hline \multicolumn{2}{|l|}{ LSD $_{0.05}$} & 0.02 & 0.018 & 25.4 & 6.3 & 0.21 \\
\hline
\end{tabular}

many growth attributes of sunflower such as plant height (Göksoy et al 2004 and Abdou et al 2011), chlorophylls (Nazarli et al 2010 and Ebrahimian \& Bybordi, 2012), and LAI (Yawson et al 2011 and Furtado et al 2016).

The interactions between irrigation levels and sowing dates in affecting physiological and growth traits of sunflower were significant (Table 3). As expected according to data recorded of irrigation levels and sowing dates, it seems that sunflower plants are grown under optimal conditions when sown in May and irrigated with $\mathrm{ET}_{100 \%}$. These circumstances induced the highest values of chlorophyll $a$, carotenoides, plant height and LAI, but the lowest value of proline. Under stress conditions, however, lower values are detected for chlorophyll a (sowing in May or June), carotenoides and plant height (sowing in April), and LAI (sowing in June).

This is true with applying 70 of crop evapotranspiration $\left(\mathrm{ET}_{70 \%}\right)$ for all aforementioned traits in addition also to $\mathrm{ET}_{85 \%}$ for LAI. So, sunflower plants were more adversely affected by water stress es- pecially with delaying date of sowing. Furthermore, proline content was the lowest when sunflower plants are grown in April or May under wellwatered condition, i.e. $\mathrm{ET}_{100 \%}$.

\section{Yield and its attributes and WUE}

Distinctive discrepancies in sunflower yield and its attributes and WUE due to sowing dates and irrigation levels and their interaction are recorded except for WUE as affected by irrigation level (Table 4).

Among the evaluated sowing dates, sowing in May as promising practice proved the potency for giving increases in head diameter and weight, seed index, seed yield and oil yield, while sowing in April and June dates were not significantly differed in affecting the seed yield and WUE (Table 4). The reductions in head diameter, head weight, seed index, seed yield, oil yield and WUE amounted to $11.8 \& 20.5,6.9 \& 15.1,10.3 \& 17.3,10.5 \&$ $12.8,13.7 \& 18.3$, and $11.8 \& 9.8 \%$ with April \& 
June sowings, respectively, as compared to May sowing. Sunflower productivity largely depends on the prevailing temperatures throughout the life cycle of the crop. In this respect and based on data in Table 1, sunflower plants were more accelerated for collecting heat in planting date of June than May. Such event led to shortening duration of different growth stages for plants of sunflower sown in June, hence reached maturity earlier. But this effect did not allow plants to utilize the gathered heat units better. Also in April planting date, plants take longer time in vegetative stage due to relatively low temperature prevailing and can not relatively utilize the heat units towards reproductive stages and consequently final product. Thus, planting before or after May resulted in decrease yield due to colder temperature early in the season and warmer weather later in the season. In May planting, it looks like that there was a relatively agreeable equilibrium between cumulative heat units and development stage from emergence till maturity. Herein, we can say it is not only important that plants gain large thermal units, but should be in harmony with different crop growth stages. Also, incompatibility of the use thermal units collected by the plant with the growth stage represents an encumbrance or stress on the plant. Kaleem et al (2009) concluded that lower yield associated with delayed planting of sunflower was due to warmer temperature during the early growth period, which accelerated stem growth and early switching over from vegetative to reproductive stage. In delayed sowing date, high temperature inhibited pollen germination and pollen tube growth, which resulted in lower seed yield (Kakani et al 2002). Barros et al (2004) indicated that with delayed sowing date, development is quicken because the crops encounter higher temperatures during the vegetative growth, shortening of the growing cycle, decline the amount of radiation intercepted during the growing season and thus a reduction of quantitative traits of sunflower. Several investigators have shown that delaying sunflower sowing date significantly decreased head diameter (Mirshekari et al 2012 and Fetri et al 2013), head weight (Abdou et al 2011), seed index (Ali et al 2004 and Asbagh et al 2009) and seed yield (Caliskan et al 2002 and Flagella et al 2002). Delaying sowing date will reduce the vegetative and reproductive growth periods which in turn reduce dry matter accumulation in plant organs (Abelardo and Hall, 2002; Abdou et al 2011).
On the other hand, $\mathrm{ET}_{100 \%}$ demonstrated superiority over than other applied irrigation levels $\left(E T_{85 \%}\right.$ \& $\left.E T_{70 \%}\right)$ in improving sunflower head diameter, head weight, seed index, seed yield and oil yield, but WUE did not affect (Table 4). Comparing to such well-watered treatment, diminishing irrigation water by $15 \%\left(\mathrm{ET}_{85 \%}\right)$ to $30 \%\left(\mathrm{ET}_{70 \%}\right)$ caused reductions of 17.6-36.9, 22.0-38.0, 16.3$33.1,18.6-32.0$ and $27.5-43.6 \%$ in the forenamed affected traits, respectively. Sunflower plants are drought-resistant, but yield and oil content are reduced if they are exposed to drought stress during the main growing and flowering periods, i.e. irrigation is a key factor for obtaining high yields (FAO, 2010). Although sunflower is known to be a drought tolerant crop or grown under dry land conditions, substantial yield increases can be achieved by supplementary irrigation, which is one of the most effective strategies to mitigate the effects of dry spells in crop production (Fox and Rockstrom, 2000; Xiao et al 2007). The reason for increase in yield under optimum irrigation was the extension of leaf area and its higher duration that allowed plants to take advantage of received light and therefore produce higher yield. Moreover, High 1000-seed weight, resulting from more irrigation, was probably due to the availability of adequate soil moisture and translocation of assimilates from source to sink during seed formation and seed ripening stages (Mirshekari et al 2012). Increasing drought stress caused significant decrease in sunflower head diameter (Akhtar and Malik, 2005 and Khaliq and Cheema, 2005), head weight (Kazemeini et al 2009), seed index (Asbagh et al 2009 and Khaliq and Cheema, 2005) and seed yield (Bukhsh et al 2009 and Bakht et al 2010).

Sowing dates and irrigation levels were markedly interacted in affecting all studied traits of sunflower yield and its attributes and WUE as shown in Table 4. In this regard, sunflower sown in May and irrigated with $\mathrm{ET}_{100 \%}$ level resulted in having the maximum values surpassing other treatments involved in this study. Furthermore, it is obviously noted that each defect in irrigation water exhibited decreasing seed yield; this is true under every sowing date. Meanwhile, seed yields produced for sowing dates under each irrigation level were as follows: May > April > June dates under $\mathrm{ET}_{100 \%}$; May > April or June under $\mathrm{ET}_{85 \%}$; but the lowest seed yields were recorded with $\mathrm{ET}_{70 \%}$ irrespective of the variations in sowing date. Compared to the 
Table 4. Irrigation and planting date influences on sunflower yield and its attributes and water use efficiency (WUE)

\begin{tabular}{|c|c|c|c|c|c|c|c|}
\hline \multirow{2}{*}{\multicolumn{2}{|c|}{ Treatment }} & \multicolumn{3}{|c|}{ Yield attributes } & \multicolumn{2}{|c|}{ Yields $\left(\mathrm{kg} \mathrm{fed}^{-1}\right)$} & \multirow[b]{2}{*}{$\begin{array}{c}\text { WUE } \\
\left(\mathrm{kg} \mathrm{m}^{-3}\right)\end{array}$} \\
\hline & & $\begin{array}{l}\text { Head diame- } \\
\text { ter }(\mathrm{cm})\end{array}$ & $\begin{array}{c}\text { Head } \\
\text { weight }(\mathrm{g})\end{array}$ & $\begin{array}{l}\text { Seed in- } \\
\operatorname{dex}(g)\end{array}$ & Seed & Oil & \\
\hline \multicolumn{8}{|c|}{ Sowing date (S) } \\
\hline \multicolumn{2}{|c|}{ April } & 14.2 & 49.8 & 4.09 & 853.9 & 279.3 & 0.45 \\
\hline \multicolumn{2}{|c|}{ May } & 16.1 & 53.5 & 4.56 & 953.6 & 323.8 & 0.51 \\
\hline \multicolumn{2}{|c|}{ June } & 12.8 & 45.4 & 3.77 & 831.4 & 264.2 & 0.46 \\
\hline \multicolumn{2}{|c|}{$\mathrm{LSD}_{0.05}$} & 0.2 & 0.6 & 0.16 & 38.8 & 12.4 & 0.02 \\
\hline \multicolumn{8}{|c|}{ Irrigation level (I) } \\
\hline \multirow{4}{*}{\multicolumn{2}{|c|}{$\begin{array}{c}\mathrm{ET}_{100 \%} \\
\mathrm{ET}_{85 \%} \\
\mathrm{ET}_{70 \%} \\
\mathrm{LSD}_{0.05}\end{array}$}} & 17.6 & 61.9 & 4.96 & 1058.2 & 378.8 & 0.49 \\
\hline & & 14.5 & 48.3 & 4.15 & 861.0 & 274.8 & 0.47 \\
\hline & & 11.1 & 38.4 & 3.32 & 719.7 & 213.7 & 0.47 \\
\hline & & 0.3 & 0.9 & 0.14 & 37.5 & 11.9 & Ns \\
\hline \multicolumn{8}{|l|}{$S \times I$} \\
\hline \multirow[t]{3}{*}{ April } & $\mathrm{ET}_{100 \%}$ & 17.2 & 63.4 & 4.77 & 1020.7 & 358.2 & 0.46 \\
\hline & $\mathrm{ET}_{85 \%}$ & 14.1 & 46.6 & 4.09 & 822.9 & 265.1 & 0.44 \\
\hline & $\mathrm{ET}_{70 \%}$ & 11.4 & 39.4 & 3.40 & 718.0 & 214.4 & 0.46 \\
\hline \multirow[t]{3}{*}{ May } & $\mathrm{ET}_{100 \%}$ & 19.6 & 68.6 & 5.56 & 1218.1 & 449.5 & 0.57 \\
\hline & $\mathrm{ET}_{85 \%}$ & 16.6 & 52.9 & 4.53 & 944.3 & 311.4 & 0.52 \\
\hline & $\mathrm{ET}_{70 \%}$ & 12.1 & 38.9 & 3.61 & 698.4 & 210.7 & 0.46 \\
\hline \multirow[t]{3}{*}{ June } & $\mathrm{ET}_{100 \%}$ & 15.9 & 53.8 & 4.55 & 935.7 & 328.7 & 0.44 \\
\hline & $\mathrm{ET}_{85 \%}$ & 12.7 & 45.5 & 3.83 & 815.7 & 247.8 & 0.45 \\
\hline & $\mathrm{ET}_{70 \%}$ & 9.9 & 37.0 & 2.94 & 742.7 & 216.0 & 0.50 \\
\hline LSD $_{0.05}$ & & 0.4 & 1.5 & 0.25 & 64.9 & 20.6 & 0.03 \\
\hline
\end{tabular}

superior practice (sowing in May $\times \mathrm{ET}_{100 \%}$ ), reductions in seed yield due to water deficit, i.e. $\mathrm{ET}_{85 \%}$ or $\mathrm{ET}_{70 \%}$, reached 32.4 \& $41.1 \%, 22.5$ \& $42.6 \%$, and 33.0 \& $39.0 \%$ for sowing in April, May, or June dates, respectively. Moreover, when speculation the alternations in WUE values, it is shown that sowing dates differed significantly in influencing WUE according to the applied irrigation level. By sowing in April, WUE did not affected; by sowing in May and as irrigation water decreased, WUE changed in a descending order; when sowing is practiced in June, however, WUE value increased under severe water deficit (i.e. $\mathrm{ET}_{70 \%}$ ) comparing to well-watered or moderately water-stressed conditions.

\section{REFERENCES}

Abd-El wahab, A.M., Awad, A., Yakout, G.M. and Griesh, M.H.1992. Effect of sunflower of some agronomic practices on sunflower production: 1- Planting date and sowing distance on growth of sunflower cultivars. Ann. Agric. Sci. Moshtohor, 30(1), 83-96.
Abdel-Nasser, L.E. and Abdel-Aal, A.E. 2002. Effect of elevated $\mathrm{CO}_{2}$ and drought on proline metabolism and growth of safflower (Carthamus mareoticus L.) seedlings without improving water status. Pak. J. Biol. Sci, 5(5), 523-528.

Abdou, S.M., Abd El-Latif, K.M., Farrag, R.M. and Yousef, K.M. 2011. Response of sunflower yield and water relations to sowing dates and irrigation scheduling under middle Egypt condition. Adv. Appl. Sci. Res., 2(3), 141-150.

Abelardo, J.V. and Hall, A.J. 2002. Effects of planting date, genotype and their interactions on sunflower yield: I. Determinants of oilcorrected grain yield. Crop Sci., 42(4), 11911201.

Aguirrezábal, L.A., Lavaud, Y., Dosio, G.A., Izquierdo, N.G., Andrade, F.H. and González, L.M. 2003. Intercepted solar radiation during seed filling determines sunflower weight per seed and oil concentration. Crop Sci., 43(1), 152- 161.

Aiken, R.M. 2005. Applying thermal time scales to sunflower development. Agron. J., 97(3), 746-754. 
Akhtar, N. and Malik, M.A. 2005. Effect of planting dates and irrigation levels on achene yield and oil content of spring sunflower, Helianthus annuus L. J. Agric. Res., 43(2), 145-155.

Ali, H., Randhawa, S.A. and Yousaf, M. 2004. Quantitative and qualitative traits of sunflower (Helianthus annus L.) as influenced by planting dates and nitrogen application. Int. J. Agri. Biol., 6(2), 410-412.

Anjum, S.A., Xie, X., Wang, L., Saleem, M.F., Man, C. and Lei, W. 2011. Morphological, physiological and biochemical responses of plants to drought stress. Afr. J. Agric. Res., 6(9), 2026-2032.

A.O.A.C. 1995. Association of Official Agriculture Chemists. Official Methods of Analysis $16^{\text {th }} \mathrm{Ed}$., Washington, DC, USA.

Arnon, D.I. 1949. Copper enzyme polyphenoloxides in isolated chloroplast in Beta vulgaris. Plant Phsiol., 24, 1-15.

Asbagh, F.T., Moghddam A.F. and Gorttapeh A.H. 2009. Influence of water stress and sowing date on sunflower yield and oil percentage. Res. J. Bio. Sci., 4(4), 478-489.

Ashrafi, E. and Razmjoo, K. 2010. Effect of irrigation regimes on oil content and composition of safflower (Carthamus tinctorius L.) cultivars. J. Am. Oil Chem. Soc., 87(5), 499-506.

Bakht, J., Shafi, M., Yousaf, M., Raziuddin and KHAN, M.A. 2010. Effect of irrigation on physiology and yield of sunflower hybrids. Pak. J. Bot., 42(2), 1317-1326.

Barros, J.F.C., DeCarvalho, M. and Basch, G. 2004. Response of sunflower (Helianthus annuus L.) to sowing date and plant density under Mediterranean conditions. Eur. J. Agron., 21(3), 347-356.

Bashir, M.A. and Mohamed, Y.M. 2014. Evaluation of full and deficit irrigation on two sunflower hybrids under semi-arid environment of Gezira, Sudan. J. Agri-Food \& Appl. Sci., 2(3), 5359.

Bates, L.S., Walden R.P. and Teare, I.D. 1973. Rapid determination of free proline for waterstress studies. Plant Soil, 39(1), 205-207.

Baydar, H. and Erbas, S. 2005. Influence of seed development and seed position on oil, fatty acids and total tocopherol contents in sunflower (Helianthus annuus L.). Turk J. of Agri., 29, 179-186.

Bukhsh, M.A., Malik, A.U., Ishaque, M. and Sadiq, S.H. 2009. Performance of sunflower in response to exogenously applied salicylic acid under varying irrigation regimes. The J. of Animal \& Plant Sci., 19(3), 130-134.

Caliskan, M.E., Cagar, E.G. and Mert, M. 2002. Effect of sowing dates on phonological development, yield and oil content of sunflower $(\mathrm{He}$ lianthus annus) in Mediterranean type environment. Ind. J. Agron., 47(3), 427-432.

Demir, A.O., Goksoy, A.T., Buyukcangaz, H., Turan, Z.M. and Koksal, E.S. 2006. Deficit irrigation of sunflower (Helianthus annuus L.) in a sub-humid climate. Irrigation Sci., 24(4), 279-289.

Dodd, I.C. 2009. Ehizosphere manipulations to maximize crop per drop during deficit irrigation. J. Exp. Bot. 60(9), 2454-2459.

Doorenbos, J., Pruitt, W.O., Aboukhaled, A., Damagnez, J., Dastane, N.G., Van Den Berg, C., Rijtema, P.E., Ashfor, O.M. and Frere, M. 1977. Guidelines for predicting crop water requirements-FAO irrigation and drainage, Rome, 24, 35-95.

Ebrahimian, E. and Bybordi, A. 2012. Influence of ascorbic acid foliar application on chlorophyll, flavonoids, anthocyanin and soluble sugar contents of sunflower under conditions of water deficit stress. J. of Food, Agri. \& Env., 10(1), 1026-1030.

El-karamity, E.A., El-serogy, S.T. and Atta Allah, S.A. 1998. Response of sunflower varieties genotype to planting dates. Zag. J. Agric., Res., 25(4), 581-593.

FAO, 2010. Sunflower Crude and Refined Oils. Viale delle Terme di Caracalla, Rome, Italy.

Farooq, M., Hussain, M., Wahid, A. and Siddique, K.H.M. 2012. Drought stress in plants. In: Plant Responses to Drought Stress. R. Aroca (ed.), pp. 1-33, Springer-Verlag Berlin Heidelberg.

Fereres, E. and Soriano, M.A., 2007. Deficit irrigation for reducing agricultural water use. J. Exp. Bot., 58(2), 147-159.

Fetri, M., Ghobadi, M.E., Asadian, G. and Rajabi, M. 2013. Effect of sowing date on yield and yield components of sunflower (Helianthus annus L.). Ann. Bio. Res., 4(2), 90-93.

Flagella, Z., Rotunno, T., Tarantino, E., Caterina, R.D. and Caro, A.D. 2002. Changes in seed yield and oil fatty acid composition of high oleic sunflower (Helianthus annuus L.) hybrids in the relation to the sowing date and water regime. Eupro. J. Agron., 17(3), 221-230.

Fox, P. and Rockstrom, J. 2000. Water harvesting for supplemental irrigation of cereal crops to overcome intra-seasonal dry-spells in the Sa- 
hel. Phys. Chem. Earth. Part B: Hydrol. Oceans Atmos., 25(3), 289-296.

Furtado, G.F., Xavier, D.A., Andrade, E.M., Lima G.S., Chaves, L.H., Vasconcelos, A.C. and Wanderley, J.A. 2016. Growth and physiological responses of sunflower grown under levels of water replacement and potassium fertilization. Afr. J. Agric. Res., 11(14), 1273-1281.

Gill, S.S. and Tuteja, N. 2010. Reactive oxygen species and antioxidant machinery in abiotic stress tolerance in crop plants. Plant Physiol. Biochem., 48(12), 909-930.

Göksoy, A.T., Demir, A.O., Turan, Z.M. and Dağüstü, N. 2004. Responses of sunflower (Helianthus annuus L.) to full and limited irrigation at different growth stages. Field Crops Res., 87,167-178.

Gomez, K.A. and Gomez, AA., 1984. Statistical procedures for agriculture research. John Wiley \& Sons, New York, USA.

Hasanuzzaman, M., Nahar, K., Alam, Md.M., Roychowdhury, R. and Fujita, M. 2013. Physiological, biochemical, and molecular mechanisms of heat stress tolerance in plants. Int. J. Mol. Sci., 9643-9684

Hossain, M.A., Hoque, M.A., Burritt, D.J. and Fujita, M. 2014. Proline protects plants against abiotic oxidative stress: biochemical and molecular mechanisms. In: Oxidative Damage to Plants: Antioxidant Networks and Signaling, P. Ahmad (Ed.), Academic Press, Elesiver USA, pp.477- 522.

Hsu, S.Y., Hsu, Y.T. and Kao, C.H. 2003. The effect of polyethylene glycol on proline accumulation in rice leaves. Biol. Plant, 46(1), 73-78.

Izquierdo, N.G., Aguirrezábal, L.A.N., Andrade, F.H., Geroudet, C., Valentinuz, O. and Pereyra, I.M. 2009. Intercepted solar radiation affects oil fatty acid composition in crop species. Field Crop Res., 114(1), 66-74.

Joksimović, J., Jovanka, A., Marinković, R. and Jovanović, D. 2006. Genetic control of oleic and linoleic acid contents in sunflower. HELIA, 29, 33-40.

Kakani, V.G., Prasad, P.V.V., Craufurd, P.Q. and Wheeler, T.R. 2002. Response of in vitro pollen germination and pollen tube growth of Groundnut (Arachis hypogaea L.) genotype to temperature. Plant Cell and Environment, 25(12), 1651-1661.

Kaleem, S., Hassan, F., Mahmood, I., Ahmad, M., Ullah, R. and Ahmad, M. 2011. Response of sunflower to environmental disparity. Natur. Sci., 9(2), 73-81.
Kaleem, S., Hassan, F.U. and Saleem, A. 2009. Influence of environmental variations on physiological attributes of sunflower. Afr. J. Biotechnol., 8(15), 3531-3539.

Kang, S.Z., Shi, W.J. and Zhang, J.H., 2000. An improved water-use efficiency for maize grown under regulated deficit irrigation. Field Crops Res., 67(3), 207-214.

Khaliq, A. and Cheema, Z.A. 2005. Effect of irrigation regimes on some agronomic traits and yield of different sunflower (Helianthus annuus L.) hybrids. Int. J. Agri. Biol., 7(6), 920-924.

Khanna-Chopra, R. 2004. Physiology of Drought and Low Nitrogen Tolerance in Crop Plants. In: Improving Maize Productivity Under Abiotic Stresses. Zaidi, P.; K. Harrington, J. de Meyer, and N.N. Singh (eds), International Maize and Wheat Improvement Center (CIMMYT), pp. 122.

KII, F. and Altunbay S.G. 2005. Seed yield, oil content and yield components of confection and oil seed sunflower cultivars (Helianthus annus L.) planted on different dates. Int. J. Agric. Biol., 7(1), 21-24.

Mirshekari, M., Hosseini, N.M., Amiri, R. and Zandvakili, O.R. 2012 .Study the effects of planting date and low irrigation stress on quantitative traits of spring sunflower (Helianthus annuus L). Romanian Agri. Res., 29, 189199.

Morison, J.I.L., Baker, N.R., Mullineaux, P.M. and Davies, W.J. 2008. Improving water use in crop production. Phil. Trans. R. Soc. B., 363, 639-658.

Munné-Bosch, S. and Peñuelas, J. 2003. Photoand antioxidative protection, and a role for salicylic acid during drought and recovery in fieldgrown Phillyrea angustifolia plants. Planta., 217(5), 758-766.

Nazarli, H., Zardashti, M.R., Darvishzadeh, R. and Najafi, S. 2010. The effect of water stress and polymer on water use efficiency, yield and several morphological traits of sunflower under greenhouse condition. Not. Sci. Biol., 2(4), 5358.

Pene, C.B.G. and Edi, G.K. 1996. Sugarcane yield response to deficit irrigation at two growth stage. Nuclear Techniques to Assess Irrigation Schedules for Field Crop. IAEA, TECDOC888, 115-129.

Qadir, G., Hassan, F. and Malik, M.A. 2007. Growing degree days and yield relationship in sunflower (Helianthus annuus L.). Int. J. Agric. Biol., 9(4), 564-568. 
Qahar, A., Khan, Z.H., Anwar, S., Badshan, H. and Ullah, H. 2010. Nitrogen use efficiency, yield and other characteristics of sunflower (Helianthus annuus L.) hybrids as affected by different levels of nitrogen. Biol. Diver. Conserv., 3, 121-125.

Rosa, P.M., Antoniassi, R., Freitas, S.C., Bizzo, H.R., Zanotto, D.L., Oliveira, M.F. and Castiglioni, V.B.R. 2009. Chemical composition of Brazilian sunflower varieties. Helia, 32, 145-156.

Sankar, B., Jaleel, C.A., Manivannan, P., Kishorekumar, A., Somasundaram, R. and Panneerselvam, R. 2007. Drought-induced biochemical modifications and proline metabolism in Abelmoschus esculentus (L.) Moench. Acta Bot. Croat., 66(1), 43-56.
Sultan, M.S., Attia, A.N. and Leilah, A.A. 1988. Response of sunflower (Helianthus annus) to sowing dates and NPK fertilization. J. Agric. Mansoura Univ., 13(1), 1-8.

Xiao, G., Zhang, Q., Xiong, Y., Lin, M. and Wang, J. 2007. Integrating rainwater harvesting with supplemental irrigation into rain-fed spring wheat farming. Soil and Tillage Res., 93(2), 429-437.

Yawson, D.O., Bonsu, M., Armah, F.A. and Afrifa, E.K.A. 2011. Water requirement of sunflower (Helianthus annuus L.) in a tropical humid-coastal savanna zone. ARPN J. Agric. and Bio. Sci., 4(1), 1-8. 